\title{
MODERNIDADE, PÓS-MODERNIDADE E CIÊNCIAS SOCIAIS*
}

\author{
Georges Benko**
}

\author{
O tema do pós-moderno presta-se maravilhosamente
}

à ativação da besteira. J. -F. Lyotard

A modernidade e a pós-modernidade não são na origem conceitos das ciências sociais. Podese qualificar estes termos mais adequadamente como os modos (os fundamentos) característicos de civilização. Apesar das diversidades simbólicas e geográficas, os dois termos impõem-se no Ocidente. No entanto, eles derivam de noções confusas, prestando-se a diversas interpretações, e que conotam globalmente toda uma evolução histórica e uma mudança de mentalidade. Inextricavelmente navega-se desde há vinte anos entre mitos e realidades em todos os domínios: as artes, a arquitetura, os costumes, a ideologia, a política etc. Modernidade e pós-modernidade nasceram de certas revoluções profundas da organização social, econômica, política, realizandose ao nível dos costumes, do modo de vida e do cotidiano.

Como não são conceitos de análise, não há leis da modernidade ou da pós-modernidade; cada uma tem meramente um conjunto particular de características, as morais canônicas dos processos coletivos conflitivos de mudança. É "A Tradição do Novo" (Harold Rosenberg, 1960). Elas jogam como idéias-força e como ideologias mestras, sublimando as contradições da histó- ria nos efeitos de civilização. Elas estão ligadas a crises históricas de estruturas. Modernidade e pós-modernidade exprimem de maneira ambígua as crises da civilização e dos conhecimentos, numa fuga contínua para a frente. As duas queriam impor uma regulação cultural nova. É por esta razão que elas se acham no centro dos debates atuais em todos os domínios das ciências humanas.

\section{I}

"Não há um sentido único da modernidade, porque a própria modernidade é uma busca de sentido" (Meschonnic, 1988).

No par que ela forma com a palavra tradição, situa-se a noção de modernidade: é moderno o que se define, em relação à sua emergência no tempo, como "presente". A palavra modernus apa-

(*) Tradução de "Modernité, postmodernité et sciences sociales", publicado originalmente como "Introduction: Modernity, postmodernity and Social Sciences", in: BANKO, G. \& STROHMAYER, U. (eds), Space and Social Theory: interpreting modernity and postmodernity. London, Blackwell, 1997.

(**) Tradução: Ricardo Castillo. 
rece no baixo latim no fim do século $\mathrm{V}$, vinda de modo, "tout juste, recentemente, agora". Modernus não significa então o que é novo mas o que é atual, contemporâneo daquele que fala. $\mathrm{O}$ apelo à tradição, em matéria estética ou do pensamento, envia a contrario a um sistema de valores que leva em conta a aquisição do passado como sendo passível de definição, estável e utilizável como modelo pela escrita, a arte ou o pensamento de hoje. Se se utiliza o termo modernidade, implica-se pelo seu emprego mesmo uma certa ruptura no tempo entre o passado e o presente, e uma ruptura entre os modelos do passado e aqueles que o presente pode ou deve elaborar.

Para retomar a fórmula althusseriana, a modernidade é, talvez, um conceito falho que testemunha a falta de um conceito: uma palavra de grande consumo cuja apropriação cognitiva, na qualidade de objeto epistemologicamente isolável, está ausente. A fragilidade teórica das tentativas de conceitualização testemunha esta constatação (identidade do termo mas diferenças do conceito, fraca carga teórica assumida pela palavra, grau de coerência pouco avançado etc.).

Pode-se referir à noção de modernidade como 1) forma distinta de temporalidade, 2) experiência social e estética inextricavelmente ligada à modernização do capitalismo, 3) projeto (inacabado), pensamento como o efeito / efeituação de uma relação de forças, e por isso atravessado por uma tensão que lhe é constitutivo.

Uma acepção normativa da modernidade não significa simplesmente que ela produz suas normas por si mesma no interior de seu espaço, que ela "não pode nem quer ir buscar numa outra época os critérios em função dos quais ela se orienta" (Habermas, 1988). Uma tal acepção, porém, sugere, primeiramente, que o grau de modernidade se mede em termos de divergência em relação às formas "tradicionais" da vida social e em segundo lugar, que o próprio tempo histórico é normativamente pontuado, identificado a um movimento homogêneo de continuidade a caráter progressivo.

No entanto, uma interpretação das conseqüências acumuladas da modernidade nos dissuade de uma tal miragem progressista. A curiosa odisséia da modernidade é semear descontinuidades e rupturas, reviravoltas e tentativas abortadas. Ela não é nem a linearidade da tradição do novo que acabaria por banalizar toda ruptura, nem "o conservadorismo pela mudança" como afirma Baudrillard.

Da mesma maneira, a noção de modernidade não está isenta de ambigüidades que refletem a escolha dos temas que o termo recobriria; a tentativa de datar a gestação do moderno, assim como suas etapas de formação, não está desprovida de obstáculos.

Habermas (1988) tentou retirar um sentido preciso do termo 'Moderno'. Ele nos indica em primeiro lugar que "é no fim do século $V$ que o termo 'moderno' foi utilizado pela primeira vez, com fins de distinguir do passado romano e pagão um presente cristão que vinha atingir o reconhecimento oficial". Segundo esta acepção o Moderno distingue-se do conceito de Tempos Modernos: "Uma crença em ser moderno existia no tempo de Charlemagne, no século XII, e durante o Iluminismo - isto é, a cada vez que uma relação renovada com a Antigüidade fez nascer na Europa a consciência de uma época nova. Por outro lado, o conceito profano de tempos modernos exprime a convicção de que o futuro já começou: ele designa a época que vive em função do futuro que se abriu ao novo que vem. [...] Somente ao longo do século XVIII que o limiar histórico, si- 
tuando-se em torno de 1500 , foi, com efeito, retrospectivamente percebido como uma renovação". Três eventos históricos maiores marcam o início dos tempos modernos: a descoberta do novo mundo, o Renascimento e a Reforma.

Segundo Wolin (1984) a emergência do Moderno corresponde à cristalização de um processo histórico mundial: "Its emergence corresponds to a world-historical process of crystallization that transpires over the course of the 15th, 16 th, and 17th centuries or the 'early modern' period. However, its definite form is not achieved until the 18th century, with the transition from the absolutist to democratic eras" ${ }^{\prime 1}$.

Uma segunda fase pode em seguida ser discernida a partir do século XIX onde o Moderno se ramifica e se translada, até o ponto de tornar-se (em meados do século XIX) modernidade estética - concebida como ruptura e rejeição estética do academicismo. Este parece ser aliás o ponto de vista de Baudrillard, para quem a modernidade "somente é percebível na Europa e a partir do século XVI, e somente adquire todo o seu sentido a partir do século XIX".

Para Habermas (1988), é principalmente o século das Luzes que transforma o moderno de uma sensibilidade amorfa em espírito do tempo: "...é somente com os ideais de perfeição exaltados pelo iluminismo francês, com a idéia, inspirada pela ciência moderna, de um progresso infinito do conhecimento e de uma progressão em direção a uma sociedade melhor e mais moral, que o olhar escapou progressivamente ao encantamento que tinha exercido sobre cada uma das épocas modernas sucessivas às obras clássicas da Antigüidade".

(1) “Sua emergência corresponde a um processo histórico mundial de cristalização que transpira ao longo dos séculos XV, XVI e XVII, ou no período 'moderno precoce'. No entanto, sua forma definitiva não está acabada até o século XVIII, com a transição da era absolutista para a democrática".
A libertação do Moderno da fascinação da Antigüidade coincide então com a tomada de consciência de seu projeto histórico. Enfim, ainda segundo Habermas, o adjetivo "moderno" somente se substantiva "muito tarde nas línguas européias dos tempos modernos - mais ou menos desde meados do século XIX - e ainda aí, no domínio das belas artes". Mas se o advento da modernidade estética é o filho legítimo do século XIX, o processo de ruptura com o modelo de arte antiga é inaugurado no início do século XVIII pela célebre "Querela dos Antigos e dos Modernos". O partido dos Modernos rejeita os dogmas do classicismo francês e assimila o conceito aristotélico de perfeição ao conceito de progresso, tal como tinha sido sugerido pela ciência moderna" (Habermas, 1988).

Pode-se constatar que o itinerário terminológico do Moderno recobre o espaço de uma grande duração histórica e conota geralmente o sentimento de uma ruptura com o passado, os tempos modernos remetem a uma configuração histórica datada (destacadamente a partir do Renascimento). O projeto moderno cristaliza-se intelectualmente no decorrer do século XVIII. Mas é somente a partir do século XIX que a modernidade adquire uma densidade social e prático-estética (modernismo). Deste ponto de vista, o século XIX constitui uma reviravolta.

Torna-se claro que o problema de datação não é independente do problema da definição/ conceitualização da noção da modernidade. Como se não bastasse, uma démarche que consistiria em (pro)por hipóteses de periodização histórica corre o risco de apagar todas as diferenças no seio do mesmo período histórico e de rejeitar assim todos os elementos que entram em dissidência com a linha de desenvolvimento hegemônico da modernidade. Como nos lembra Jameson "one of the concerns frequently araised by periodizing 
hypotheses is that these tend to obliterate difference, and to project an idea of the historical period as massive homogeneity (bouned on either side by inextricable chronological metamorphoses and punctuation marks) $)^{\prime \prime 2}$.

Mas o maior perigo vem do fato de considerar a modernidade (e o processo de modernização) em termos de essência (racional, contratual, lógica de complexificação) que se objetivaria nas estruturas históricas. Este ponto é decisivo para a crítica da concepção habermasiana da modernidade. A diversidade das mutações que marcam a "presença massiva" da modernidade não pode ser interpretada simplesmente como evidência concreta da finalidade emancipatória do projeto moderno (a modernidade como aplicação do projeto moderno, o Moderno torna-se modernidade, a saber, determinação concreta do Moderno, estado do Moderno, em outras palavras: substantivo que substituiu o adjetivo). A modernidade não é a aplicação/concretização de um projeto pré-determinado. Caso contrário, ela apareceria ordenada pelo desdobramento da logocentricidade histórica moderna, que se tornaria sua força motriz. As idealidades do projeto moderno imporiam-se como o motor propulsor do processo de mise en modernité. A constatação destes impasses atuais (a derrota da modernidade em todos os fronts) se traduziria automaticamente pela bancarrota do projeto moderno. Uma tal interpretação é favorável à emergência de posições "pós"-modernas que condenam o projeto moderno como intelectualmente superado e eticamente reprovável, ou mesmo reacionário.

Ora, a modernidade como experiência histórica não é uma ordem inexorável contida en

(2) “Uma das inquietações freqüentemente provocadas por hipóteses de periodização é que estas tendem a apagar a diferença e projetar uma idéia do período histórico como homogeneidade massiva (atada em cada lado por metamorfoses cronológicas inextricáveis e marcas de pontuação)" germe no projeto moderno, projeto que, por sua vez, prefiguraria seu destino. Ao contrário, o próprio projeto moderno, sendo parte orgânica da formação histórica moderna, constitui-se de maneira agonale como resultado de uma relação de forças, até mesmo como expressão de tensões coaguladas que condensam ao nível discursivo as distensões imanentes à modernidade. Somente então uma conceitualização da modernidade em termos de modernidade capitalista poderia dar conta do caráter contraditório desta experiência histórica e pensar o itinerário do projeto moderno a partir das contradições do mundo real.

Esta afirmação significa que o projeto moderno é o resultado do compromisso, de ambigüidades, mesmo de amálgamas. Ele é constantemente questionado por resistências e atravessado por contra-tendências, continuamente atacado por forças materiais ou intelectuais estabelecidas. Como se não bastasse, ele sofre transmutações e translações pela dinâmica de suas próprias cisões. Como ressalta A. Wellmer (1985), "from early on, modern society has repeatedly mobilised strong counterforces against the Enlightenment as a processus of rationalization; examples are the German Romantics, the young Hegel, Nietzsche, the early Marx, Adorno, the anarchists; a large part of modern art belongs to these counter tendancies" ${ }^{\prime \prime}$. Por outro lado, o próprio movimento socialista desafiou progressivamente a unidade da razão iluminista inserindo uma dimensão de classe no seio da modernidade capitalista: "there are strong objections even within modernism (think of Chaplin's Modern Times) to the idea that the machine, the factory and the rationalized city

(3) "desde cedo, a sociedade moderna repetidamente mobilizou forças contra o iluminismo como um processo de racionalização; os românticos alemães, o jovem Hegel, Nietzsche, o jovem Marx, Adorno, os anarquistas são alguns exemplos; uma grande parte da arte moderna pertence a estas contra-tendências". 
provide a sufficiently rich conception to define eternal qualities of modern life" (Harvey, 1989).

Em suma, se o projeto moderno não tem a coerência pressuposta, é porque ele faz parte desta realidade mutante (portanto inacabada), transitória e em fuga, que é a modernidade capitalista. Realidade cujos campos e modos de desdobramento ficam a explicitar.

Proponho uma classificação em três ordens da experiência histórica da modernidade:

- a modernidade como experiência social global, indissociável dos processos de modernização capitalista do espaço produtivo e estatal, tornada hoje forma hegemônica e universal;

- a modernidade como experiência de vida cotidiana, melhor, logica capilar de cotidianeidade e linha dominante do desenvolvimento do vivido, mesmo do modo de percepção do tempo histórico;

- a modernidade como busca (e inquietude) cultural, referencial, que fascinava Rimbaud ("épreciso ser absolutamente moderno") e Baudelaire, dito de outra maneira, herança ligada à produção estética dos avant-gardes (modernismo).

Uma discussão sobre a "modernidade" é freqüentemente uma confrontação entre numerosos fantasmas, alguns conhecimentos parciais e extrapolações sem fundamento. Importa então decidir, depois de pesquisar, se a palavra "moderno" é apenas uma etiqueta cômoda fixada sobre alguns séculos de história ou se ela designa uma metamorfose de toda a cultura, ou seja, de nossas relações com a natureza, com outros ho-

(4) "há fortes objeçōes mesmo dentro do modernismo (pense nos Tempos Modernos de Chaplin) à idéia de que a máquina, a fábrica e a cidade racionalizada fornece uma concepção suficientemente rica para definir qualidades externas da vida moderna" mens e, ao mesmo tempo, de nossas concepções do divino.

De fato, "moderno" designa o que aconteceu depois de uma mudança radical, e se aplica tanto ao homem quanto ao seu meio ambiente. $\mathrm{O}$ mundo moderno é aquele que sucede ao mundo agrário; com ele surgiu uma nova visão do mundo que era completamente diferente daquela que a precedeu. A modernidade afeta o homem em primeiro lugar, o mundo do homem em seguida. É portanto perfeitamente possível dar um sentido unificado ao termo modernidade: trata-se de uma nova lógica que estrutura um campo semântico desconhecido do passado, a lógica de uma nova visão do mundo. Ser moderno é viver num mundo que não é mais aquele do passado e que é preciso abordar com outros métodos.

É portanto indispensável observar que a nova visão do mundo se manifesta em vários domínios, onde a nova lógica engendra estruturas que não têm nada de comparável. E a tomada de consciência das mudanças que intervém em cada um deles não se faz no mesmo ritmo.

As quatro revoluções que determinam a passagem à modernidade são as seguintes: uma revolução científica, uma revolução política, uma revolução cultural, uma revolução técnica e industrial. Cada uma destas revoluções comporta etapas; pode-se ser mais ou menos moderno em cada domínio. Por outro lado, é possível efetuar uma ou várias revoluções sem ter integrado a outra ou as outras. O exame destas quatro revoluções pode permanecer global, na medida em que se trata somente de captar o que faz a modernidade. Avançar a análise até a captura da nova lógica e da mudança mental que ela acarreta é um outro problema. Mas a nova lógica é o que define a modernidade através das modernidades. Trata-se apenas aqui de designar os lugares de seu surgimento. 
Estas quatro revoluções estão interligadas, mas de maneira flexível. Cada indivíduo é afetado diferentemente por cada uma delas. Pode-se ser moderno em um domínio e tradicional num outro, mesmo quando os dois domínios estão ligados. Por exemplo, pode-se ser moderno em política e apegar-se a um modo de produção mais tradicional. A defasagem pode ser ainda maior quando os dois domínios são menos interdependentes. Um científico, por exemplo, pode ser moderno na sua esfera própria, mas permanecer tradicional culturalmente; um teólogo pode ter integrado a revolução cultural sem ter nada compreendido sobre os desafios dos fundamentos lógicos na revolução científica. $\mathrm{O}$ jogo destas modernidades diferentes que não progridem de maneira simultânea nos indivíduos torna-se ele mesmo um problema político na sociedade moderna. Um problema que se complica ainda pelo fato de que se pode ser mais ou menos moderno em cada uma das esferas marcadas por uma revolução que comporta etapas. Visões modernas do mundo já se sucederam. Ao ponto em que alguns falam de pós-modernidade.

A modernidade é um sistema cultural dado como definitivo por algum tempo no século XIX, antes de questionar, hoje, seus próprios fundamentos, não para voltar atrás, mas para encontrar o terreno onde pode germinar uma nova cultura (Jeannière, 1987).

Mas pode-se falar de pós-modernidade? Há um ponto crítico na história contrastada dos quatro domínios distintos, e sobretudo no meio sócio-cultural que resulta de suas interferências, que nos obrigariam a vislumbrar um novo ponto de partida? Um novo mundo recentemente apareceu, tão diferente do mundo moderno quanto o mundo de Newton e Einstein o eram do mundo simbólico dos agricultores da Idade Média?
Mais freqüentemente, aqueles que falam de pós-modernidade focalizam sua atenção na revolução cultural e na revolução industrial. A história já longa destas duas revoluções lhes parece comportar uma ruptura essencial que marca um antes - a modernidade, e um depois - a pós-modernidade.

Sem que se possa datá-la com precisão, a ruptura cultural aparece com evidência por volta de 1968. O que é observado ressalta principalmente de uma mutação dos valores: a anarquia parece preferível à hierarquia, o jogo ao projeto estruturado, a "desconstrução" toma o lugar da criação, a liberdade individual é preferida aos valores coletivos etc.

No domínio econômico, é a crise que marca a reviravolta. A sociedade industrial torna-se pós-industrial e o sistema produtivo fordista deixa seu lugar ao pós-fordismo. As tecnologias da informação e da comunicação invadem o mundo econômico e os lares. No campo político o Estado-providência desaparece, tanto quanto os países comunistas; o Estado liberal e o mercado dominam. Poder-se -ia dizer que a pós-modernidade caracteriza também a passagem das certezas de uma ciência positiva triunfante para uma incerteza generalizada.

Em suma, todos aqueles que falam de pósmodernidade constatam que o mundo de hoje atravessa uma grave crise. Pode-se ainda falar de modernidade quando todas as certezas da velha modernidade desmoronaram, inclusive no domínio científico? A epistemologia das ciências também atravessa uma grave crise, uma crise da qual Paul Feyerabend (1979) é sem dúvida uma das melhores testemunhas.

O sintoma de uma mudança maior é a crise da epistemologia científica. Mas deve-se pensar que uma tal crise, tão profunda e generalizada ela seja, inaugura uma nova era histórica? Talvez 
a crise seja demasiadamente grave para não desembocar numa nova visão do mundo? Talvez...

É difícil decidir se o pós-modernismo corresponde a uma autêntica mudança de episteme, ou de paradigma, no sentido de Kuhn, e se ele deu lugar a formas originais, ou se ele somente reciclou procedimentos antigos num contexto diferente. Há continuidade ou ruptura com o modernismo, e em caso afirmativo, positiva ou negativa?

A lógica da modernidade é aquela de três grandes dispositivos e de suas coações: produção-organização-poder; sua retórica é aquela dos movimentos de mudança e de experimentação, de tensões em direção à novidade e ao inédito. Eles operam ao inverso um do outro, eles se contradizem no afrontamento, eles provocaram assim uma crise da representação, uma interferência dos pontos de referência, um estouro no seio da sociedade e da cultura que aparecem ainda mais fragmentadas. Nas brechas, a corrente do pós-modernismo se introduziu no decorrer dos anos 1960 - 1970, desde o princípio demonstrando uma afinidade com o contraditório, o qual definitivamente questionou suas próprias credenciais. Como é possível estar situado no tempo presente e ao mesmo tempo transcender a modernidade imediata?

Na origem, este desenvolvimento era uma crítica das convenções, das formas e dos objetivos que definiam a teoria e a prática arquiteturais. Os modernistas da primeira geração, destacadamente aqueles que fundaram o Bauhaus - o Grande Atelier do século XX - e aqueles que receberam sua influência, são questionadas. A rejeição da tradição, a produção de outras formas e o emprego sistemático dos novos materiais, o "funcionalismo absoluto" e a pesquisa da inte- gração de todas "as atividades de um lugar" não têm mais força de regra. O processo foi descrito por C. Jenks (1980) como "a inversão e a modificação parcial da antiga linguagem arquitetural". A formulação é atenuada, enquanto as "contradições em arquitetura" manifestam-se cedo e com força. O pós-moderno arquitetural se caracteriza particularmente por suas alusões ao passado, suas reminiscências históricas. O novo impulso da arquitetura religiosa nos Estados Unidos tem valor ilustrativo; ele rompe com a produção "autenticamente nacional" que, até uma época recente, foi "profundamente racional, empírica e utilitária"; ele evoca alusivamente as catedrais medievais, as basílicas da Renascença italiana, ou as igrejas rurais anglicanas; ele recorre mais ao simbolismo religioso e às referências litúrgicas. Seus promotores - "os arquitetos da escola metafísica" - abrem, foi dito, "as portas de uma era pósmoderna tingida de romantismo".

O pensamento pós-modernista atingiu as artes e a cultura no sentido amplo, a literatura, alguns dos modos de conhecimento e a filosofia. Em sua versão mais teorizada, ele se inspira em primeiro lugar na dialética negativa da Escola de Frankfurt e nos trabalhos de J. Habermas que, por ocasião de uma recente contribuição, faz menção àqueles "que pensam ter deixado atrás de si todos os paradigmas e entraram na clareira anarquista da pós-modernidade". Ele leva em consideração "a desconfiança face às grandes sistematizações e generalizações" e nota por sua parte, relacionando-o à filosofia, o desenvolvimento de um sincretismo que conduz a integrar no saber, "às vezes de maneira apressada e numa simultaneidade que não leva a nenhuma escolha, ... o que estava até então rechaçado". J. -F. Lyotard opõe uma modernidade "crítica" a uma pós-modernidade que "seria mais bem empirocrítica ou pragmatista". Ele apresenta o pós-modernismo 
sob o aspecto de um "estado de espírito", isto é, uma maneira de descrever a mutação das sociedades, das culturas e do saber desde a ruptura dos anos 1950, momento em que o pós-guerra termina, momento de abertura das expansões em todos os domínios de ação e das transformações societais as mais generalizadas. Este estado intelectual encoraja a rejeição: recusa representações unívocas do mundo, visões totalizantes, dogmas e, também, reconhecimentos e afirmações de sentido. Ele aparece como uma erosão dos pontos de referência, uma interferência das maneiras de ver e de significar, uma perda de confiança nas teorias. Lyotard mostra o enjeu que, segundo ele, se impõe hoje ao pensamento filosófico. É preciso evitar cair no "pragmatismo positivista ambiente" tanto quanto no dogmatismo. Ambos são hegemônicos, a única resposta, no momento, é operar por "micrologia".

O pós-modernismo apresenta-se como um movimento de desconstrução, de quebra da hierarquia dos conhecimentos e dos valores, de tudo o que contribui a uma formação de sentido, de tudo o que foi construído em paradigma ou em modelo. Estimou-se que "ele não explica nada, afirmando no entanto que se pode viver tranqüilo num universo sem explicação". Sob uma de suas faces, ele esconderia um cinismo do acomodamento, da ordenação, um nihilismo banalizado e afetado, um consentimento resultante da passividade e da astúcia cotidiana; ele se satisfaria com a ambigüidade; ele permaneceria exterior a toda elaboração de um projeto político ou utópico. Sob uma outra de suas faces, ele mostraria uma capacidade expressiva liberada, uma exigência de criatividade livremente exercida e propícia à coexistência dos estilos, uma abertura a todas as experimentações, múltiplas, estilhaçadas e pouco preocupadas com suas chances de durar. Deste último aspecto, a sucessão rápida dos movimentos da jovem pintura traz a ilustração. Os "Grafitistas", inspirados pelos grafites agressivos das periferias urbanas, praticam uma arte selvagem onde o inocente e o trivial se conjugam. Os pintores da "Bad Painting" jogam com o inacabado, com a incompetência, com a confusão a fim de restituir uma imagem ao seu estado nascente, provocativamente indiferente ao critério de realismo. O "Novo Expressionismo" reivindica uma violência, uma objeção, um direito ao excesso no escárnio e na carga emotiva, ao jogo com a falsa grandeza, manifestando afinidades com a literatura de horror e da crueldade. A "transavant-garde", sucedendo a arte conceitual, quer restabelecer "o exercício soberano da pintura" colocado ao serviço da confiança pessoal e da anedota, associadas a temas míticos e oníricos; segundo o iniciador do movimento, este "deslocou as coisas" e quebrou a visão unitária do mundo "professando uma visão fragmentária e uma experiência nômade". Última a chegar, a "Pintura anacrônica": ela recorre à tradição, ela pratica a alusão aos grandes períodos da história da arte, ela reencontra o neo-classicismo ou o realismo fantástico; é uma pintura da nostalgia que tempera um humor discreto.

As linhas de fragmentação, e depois de recomposição, que traçam o esboço da modernidade, e depois de pós-modernidade, revelam-se neste rápido inventário da jovem pintura. As novas orientações da literatura tornam-se igualmente reveladoras. Para além dos ideais, das ideologias, das ilusões devastadas, se formula uma pesquisa explorando todas as vias da escrita, relacionando a experiência das vidas estilhaçadas, recorrendo a uma mobilidade que restitui a abundância dos eventos com desenvoltura e ironia. Da modernidade à pós-modernidade, uma certa continuidade prossegue. A segunda exaspera aspectos da primeira, ela impele ao extremo sua retóri- 
ca. Ambas dão conta de uma revolução das paisagens sociais e culturais, de uma quebra das ligações tecidas no passado entre os homens e seus grupos e suas obras, de uma tentativa de orientação dos fragmentos significativos de um futuro a informar. Elas tentam uma exploração de espaços mal ou não orientados, desconhecidos ou quase. Elas desorientam. As palavras de Ulisses de volta à Ítaca poderiam ser pronunciadas abordando estes pontos: "Ao país de qual mortal eu vim? ... E eu mesmo, onde vou?".

"Yet, if the postmodernism is a historical phenomenon, then the attempt to conceptualize it in terms of moral or moralizing judgement must finally be identified as a category-mistake." (Jameson, 1984).

\section{$* * *$}

No espaço de vinte anos, o conceito de pósmodernidade tornou-se um dos mais largamente usados entre aqueles em curso nas discussões dizendo respeito à arte, à literatura ou à teoria social. A noção de "pós-modernidade" é parte de uma rede de conceitos e de modos de pensamento em "pós"; dou alguns exemplos: sociedade pósindustrial (Bell, 1973; Touraine, 1969), pós-estruturalismo (Bonnett, 1989; Dews, 1987; Harland, 1987; Pratt, 1993), pós-fordismo (Amim, 1994; Harvey, 1989), pós-comunismo (Fejtö, 1992), pósmarxista (Peet; Watts, 1993), pós-cristão (Poulat, 1994; Lambert, 1995), pós-hierárquico (Mills, 1994), pós-burocrático (Heckscher; Donnellon, 1994), pós-liberalismo (Gray, 1993), pós-desenvolvimento (Escobar, 1992), pós-freudiano (Amar et

(5) "Se o pós-modernismo é um fenômeno histórico, então a tentativa de conceituá-lo em termos de moral ou julgamento moralizante deve finalmente ser identificada como uma falsa categoria (categorymistake)". al., 1995), pós-imperialismo (Schuurman, 1993), pós-filosófico (Fougeyrollas, 1994), pós-urbano (Kling et al., 1991), pós-colonial (Young, 1997; Harasym S., 1990; Aschcroft et al., 1994), pós-capitalismo (Vakaloulis, 1994a), entre as expressões mais evocadas. Uma boa parte das teorias "se moderniza" também em "pós": Pós-modernized Simmel (Weinstein, 1993), a localização das empresas pós-weberiana (Scott, 1988; Benko, 1991), a teoria pós-impasse (Schuurman, 1993), a cultura pós-televisão (D’Agostino; Tafler, 1994) e a sociologia pós-lararsfeldiana (Pasquier, 1994), e mesmo a administração pública ou ainda o marketing tornam-se pós-modernos (Fox; Miller, 1995; Brown S., 1995). A pós-modernidade é colocada em relação com: o feminismo (Bondi, 1990; Nicholson, 1990; Soper, 1990), a ecologia (Beck, 1992; Ferry, 1992), a planificação (Dear, 1986, 1991; Soja, 1993), o espaço (Bonnett, 1992; Harvey, 1990) etc. Geografia, sociologia, filosofia, literatura, arquitetura, artes plásticas entraram em seu período de pós-modernidade. O "Pós-" é incontornável! O fim do século XX conjuga-se em "pós-". Mal estar ou renovação das ciências sociais, das artes, da filosofia inserem-se na atmosfera da época (l'air du temps).

Não é de se estranhar que o "pós-" em todos estes contextos seja ambíguo. Não quer somente dizer depois. O depois pode implicar tanto a continuidade quanto a ruptura. Mas se se trata de continuidade, por que um prefixo e uma nova palavra? Objetivamente, ele separa. Sem conseguir, semanticamente, se destacar. Voltado para a ruptura e a continuidade ao mesmo tempo. Uma verdadeira ruptura encontra seu nome. Permanece do contínuo no "pós-". E do linear.

Pós-moderno. Romper, no mito de ruptura da modernidade, é um gesto moderno por excelência. Para romper com o moderno, o pós-moderno deve repetir o moderno. 
Pós-moderno, este termo federador de uma pluralidade de tendências peca por um tipo de indeterminação quanto à definição, de acordo com a heterogeneidade de seu conteúdo (elíptico, codificado, parcial e provisório etc.). Trata-se, como o explica um dos principais teóricos do pósmodernismo, de um conceito "equivocal, disjunctive category, doubly modified by the impetus of the phenomenon itself as by the shifting perceptions of its critics ${ }^{6 \prime}$ (Portoghesi, 1982).

As origens do termo permanecem incertas. Ihab Hassan nos lembra que Federico de Onis "used the word postmodernismo in its Antologia de la poesia española e hispanoamericana (1882-1932) published in Madrid in 1934; and Deully Fitts picked it up again in his Anthology of contemporary Latin-American petry of 1942 . Both meant thus to indicate a minor reaction to modernism already latent within it, reverting to the early 20th century"7 (Hassan, 1982, p. 260-261). O termo também apareceu "in Arnold Toynbee's A Study of History as early as D. C. Somervell's first volume abridgement in 1947. For Toynbee, Postmodernism designated a new historical cycle in western civilisation, starting around 1875, which we now scarcely begin to discern"

Daniel Charles (1985, p. 138) o encontrou no pintor inglês Chapman que, em 1880, definia-

(6) "equivocado, categoria disjuntiva, duplamente modificada pelo ímpeto do próprio fenômeno como pelas percepçōes mutantes de suas críticas."

(7) "usou o termo pós-modernismo na sua Antologia de la poesia española e hispanoamericana (1882 - 1932) publicada em Madrid em 1934; e Duelly Fitts recuperou-o em sua Antologia da poesia latinoamericana de 1942. Ambos tencionavam indicar uma reação secundária ao modernismo já latente dentro dele, voltando ao começo do século $X X$.

(8) "em um Estudo da História de A. Toynbee tão cedo quanto o primeiro volume reduzido de D. C. Somervell em 1947. Para Toynbee, o pós-modernismo designava um novo ciclo histórico na civilização ocidental, começando por volta de 1875, o qual mal começamos a discernir." se como "pós-moderno", moderno de outra maneira, em relação aos impressionistas franceses. Wolfgang Welsh (1988) descobriu o adjetivo "pósmoderno" no escritor alemão Rudolf Pannwitz, um "nietzschiano" do começo do século, que proclamava num texto de 1917: "Fortificado pelos esportes, educado militarmente, excitado pelo religioso, o homem pós-moderno é um molusco com carapaça, uma mistura a porções iguais de decadente e de bárbaro, levado pela onda saída do turbilhão fecundo da grande decadência da revolução radical do nihilismo europeu".

Mas o termo "pós-moderno" entra em uso aproximadamente em meados dos anos 1960, com a instauração, mais ou menos no conjunto do mundo ocidental, de um clima desfavorável ao modernismo (Habermas, 1981b, p. 965). Correntes artísticas e tendências epistêmicas entram em colisão com as figuras instituídas da modernidade, invadindo a arquitetura, o teatro, o cinema, a música e a dança, a filosofia, a psicanálise, a teologia e a historiografia, a literatura e a crítica literária, enfim as tecnologias cibernéticas, as ciências e a epistemologia.

Problema: esta evolução limita-se simplesmente à emergência de uma nova constelação de idéias, combinada com novas práticas estéticas? Ou conota uma verdadeira revolução que se iniciaria na época do reino do simulacro e da desrealização quase-acabada do mundo ("um fim do mundo sem tragédia" segundo a fórmula de Baudrillard)? Melhor: quais são os fenômenos cujo pós-moderno seria a tradução?

- Uma mudança na função social da esfera cultural, uma inflação da forma estética que invade completamente as práticas sociais da quotidianeidade (a Image Ridden World)?

- A erosão da força autolegitimadora das Narrativas especulativas, a implosão da idéia de progresso e o desuso da represen- 
tação unitária de um sujeito - foco exclusivo de produção de sentido?

- As mutações políticas e sociais atuais de dimensão histórica, a saber, a nova fase de modernização social do sistema capitalista que acentua as tensões da modernidade planetária?

O pós-moderno recobre todos estes fenômenos. Ele remete num único e mesmo movimento a uma lógica cultural que valoriza o relativismo e a (in)diferença, a um conjunto de processos intelectuais que oferecem estruturações significativas do mundo extremamente flutuantes e indeterminadas, ao contrário da categorização moderna do mundo, e, enfim, a uma configuração de tratos sociais que significariam a irrupção de um movimento de descontinuidade no seio da condição moderna (mutações dos sistemas produtivos e crise do trabalho, eclipse da historicidade diante da atemporalidade do efêmero, crise do individualismo moderno e onipresença da cultura narcisista de massa etc.). Dito de outra forma, a condição pós-moderna evoca uma visão / mudança cultural, uma mutação intelectual no seio do humanismo ocidental e uma experiência histórica (de sensibilidade) particular, ancorada em um suporte histórico específico. Em particular, ela é uma expressão de uma reconciliação aberta com o mundo do fetichismo da mercadoria, a atitude de desculpabilização face às contradições da modernidade, até mesmo a tradição do "esgotamento" da herança moderna.

Este desdobramento pluridimensional impede que se dê um sentido unificado ao pós-moderno. Desta maneira, o pós-moderno apresenta-se sob uma forma confusa, refém de suas sedimentações semânticas imbricadas; às vezes suplemento de alma cultural da sociedade pós-industrial, às vezes versão "radical" da "pós-histó- ria" ou figura intelectual aproximando-se do pósestruturalismo etc. De fato, sua pertinência como esquema cronológico e tipológico encontra-se erodida.

\section{* * *}

Umberto Eco (1985) estima que o pós-moderno não é uma tendência que se pode delimitar cronologicamente, mas uma categoria espiritual, ou melhor, um Kunstwollen, uma maneira de operar. Poder-se -ia dizer que cada época tem seu pós-moderno, da mesma maneira que cada época teria seu maneirismo (se bem que me pergunto se pós-moderno não é o nome moderno do maneirismo na qualidade de categoria meta-histórica).

Eco prossegue numa defesa crítica da pósmodernidade. A resposta pós-moderna ao moderno consiste em reconhecer que o passado, dado que ele não pode ser destruído porque sua destruição conduz ao silêncio, deve ser revisitado: com ironia, de uma maneira não inocente. Ele desenvolve esta idéia através de um exemplo da vida cotidiana e literária. Ele pensa na atitude pósmoderna como na atitude daquele que amaria uma mulher muito culta e saberia que ele não pode dizer a ela: "Eu te amo desesperadamente", porque ele sabe que ela sabe (e ela sabe que ele sabe) que estas frases, Barbara Cartland já as escreveu. No entanto, há uma solução. Ele poderá dizer: "Como diria Barbara Cartland, te amo desesperadamente". Então, tendo evitado a falsa inocência, tendo dito claramente que não se pode falar de maneira inocente, este terá no entanto dito a esta mulher o que ele queria dizer-lhe: que ele a ama e que ele a ama à maneira de uma época de inocência perdida. Se a mulher joga o jogo, ela terá recebido uma declaração de amor. Nenhum dos dois interlocutores se sentirá inocente, ambos jogarão conscientemente e com prazer o jogo 
da ironia... Mas ambos terão conseguido uma vez mais falar de amor.

O crítico americano neo-marxista Fredric Jameson (1991), (contrariamente a Eco) propõe situar o pós-modernismo como uma etapa historicamente bem determinada da evolução dos regimes de pensamentos e analisa a mudança em relação ao pensamento modernista. O pós-modernismo, como dominante cultural da lógica do capitalismo avançado, caracteriza-se pela crítica dos "modelos de profundidade": o modelo dialético da essência e da aparência, e seus conceitos de ideologia e de falsa consciência; o modelo existencial da autenticidade que o funda. E finalmente a grande oposição semiológica entre significante e significado que reinou nos anos sessenta e setenta.

Substitui-se a isto um "modelo de superfície" ou melhor um "modelo de superfícies múltiplas". O mundo, constata Jameson, "perde sua profundidade e ameaça de se converter um uma superfície brilhante, uma ilusão estereoscópica, um fluxo de imagem de filme sem densidade". Celebrando a apoteose do espaço em relação ao tempo, e o desaparecimento do referente histórico, este modelo de superfície está em fase com a nova superfície da expansão global do capital transnacional, sua circulação em tempo real nas redes telemáticas, os fluxos de imagens ao mesmo tempo universais e fragmentadas.

Para Jameson ainda, o pós-modernismo reforça a lógica do capitalismo, negando a autonomia da arte que oferecia, de acordo com Adorno, a última garantia de independência em relação à cultura comercial burguesa. Do modernismo, o pós-modernismo abandonou a dimensão subversiva ou crítica, em proveito de uma co-habitação simples com a sociedade pós-industrial. Jameson deixa no entanto aberta, sem precisar, a possibilidade de que o pós-modernismo resista também à lógica capitalista.
Mas Gianni Vattimo vê também uma estreita correspondência entre a teoria pós-moderna, se não com Baudelaire, ao menos com estes dois críticos da filosofia clássica: Nietzsche e sua doutrina do eterno retorno e a "ultrapassagem" ("dépassement") da metafísica em Heidegger. O essencial da pós-modernidade é de fato a negação do que é a noção moderna por excelência, aquela de "ultrapassagem" ("dépassement"), justamente como Nietzsche e Heidegger desafiaram o pensamento europeu "recusando-se a propor uma 'ultrapassagem' ('dépassement') crítica que nos teria aliás mantido ainda cativos no interior da sua própria lógica de desenvolvimento". A pós-modernidade representaria então uma virada autêntica em relação à modernidade. Vattimo escreve (1987): “O 'pós-' de pós-moderno, indica de fato uma despedida, um abandono que, tentando substrair-se às lógicas de desenvolvimento da modernidade, e particularmente à idéia de uma 'ultrapassagem' ('dépassement') crítica em direção a uma nova fundação, dá prosseguimento aos esforços de Nietzsche e Heidegger em sua relação 'crítica' com o pensamento ocidental".

De todos os intérpretes do pós-moderno, Vattimo parece dar-lhe o mais alto valor filosófico, aquele de uma saída do moderno, não por uma ultrapassagem (dépassement) nem por uma prorrogação (relève), mas, escreve ele, por uma "sobrepujação" ("surmontement"), como quando alguém se recupera de uma doença, vencendo-a.

Então, a pós-modernidade não seria simplesmente uma crise a mais entre aquelas que pontuaram a história da modernidade, a última em data das negações modernas, o mais recente episódio da revolta do modernismo conta ele mesmo, mas sim o desenlace mesmo da epopéia moderna, a tomada de consciência de que o "projeto moderno", como diz Habermas, não será jamais terminado. O fim da crença no progresso 
não implica no entanto em uma queda apocalíptica na irracionalidade. "Pensamento fraco" segundo Vattimo, a pós-modernidade propõe simplesmente uma maneira diferente de pensar as relações entre a tradição e a inovação, a imitação e a originalidade, que não privilegia mais por princípio o segundo termo. Uma longa série de oposições modernas perdem sua acuidade: novo / velho, presente/passado, esquerda/direita, progresso/reação, abstração/figuração, modernismo/realismo, avant-garde/kitsch. A consciência pós-moderna permite também reinterpretar a tradição moderna, sem continuar a vê-la em termos de uma imagem de esteira rolante e a grande aventura do novo. Desde que o messianismo foi descartado, revelaram-se as contradições, todos os acasos, todas as resistências do modernismo em sua própria marcha adiante. Restabelecemo-nos da visão teleológica do modernismo, o que não quer dizer que "tudo seja bom", mas, mais modestamente, que não se pode mais recusar uma obra sob pretexto que ela seria ultrapassada ou retrógrada. Se a arte não persegue, de ultrapassagem crítica em ultrapassagem crítica, algum fim de abstração sublime, como as narrativas ortodoxas da tradição moderna o desejavam, então gozamos de uma liberdade desconhecida desde um bom século. Certamente, não é fácil usar esta liberdade!

\section{II}

Devo adiantar que alguma coisa da noção de modernidade foi arrebatada pela corrente pósmoderna. Finalmente, o maior interesse da pósmodernidade reside talvez no fato de que não se pode mais, hoje, falar de modernidade sem colocar questões.

A idéia de modernidade somente dominou o pensamento até a construção da sociedade in- dustrial. A luta contra o passado, a confiança absoluta na razão dava à imagem da sociedade moderna uma força e uma coerência que rapidamente desapareceu quando a experiência toma o lugar da esperança, quando a sociedade nova tornou-se realidade e não mais somente o avesso daquela que se queria destruir ou ultrapassar (Tourraine, 1988).

A história da modernidade é aquela da emergência de atores sociais e culturais que crescentemente perderam a fé na modernidade como definição concreta do bem. Os primeiros a rejeitar a modernidade, seguindo os exemplos de Nietzsche e de Freud, foram os intelectuais; e a corrente mais influente do pensamento moderno, de Horkheimer e de seus amigos de Frankfurt a Michel Foucault, impulsionou ainda mais longe uma crítica da modernidade que acabou por isolar completamente os intelectuais numa sociedade que eles designavam com desprezo como sociedade de massa. Mas, ao lado deles, num sentido às vezes próximo destas críticas intelectuais, mas mais freqüentemente muito distante delas, as nações e sua paixão pela independência, sua história e sua identidade, tomam uma importância crescente, ao ponto em que o século XX será aquele das nações como o século XIX tinha sido aquele das classes, ao menos nos países modernizados. Mais tarde as empresas, nos Estados Unidos em primeiro lugar, depois no Japão e na Europa, tornam-se atores cuja potência excede às vezes aquela dos Estados nacionais, dos centros de decisão política, mais do que simples agentes econômicos. Enfim, nos Estados Unidos em primeiro lugar, depois na Europa e mais tardiamente no Japão, emerge o consumo de massa, seguido pelas comunicações de massa que fazem entrar na vida pública o mundo dos desejos, do imaginário, e mais simplesmente do corpo que o racionalismo moderno tinha rejeitado, reprimi- 
do ou enclausurado. Tanto quanto a racionalidade instrumental estabeleceu sua rede de relações entre estes atores sociais e culturais, a modernidade manteve-se intacta, e pode-se falar de sociedade industrial, até mesmo neo-ou hiper-industrial. As sociedades mais modernas sentem-se ameaçadas de desintegração, mas a importância das técnicas em seu funcionamento permite-lhes reagir combinando formação técnica e defesa de um certo ascetismo; elas são defendidas com grande força pela escola, que se considerou, sobretudo na França, como o defensor do racionalismo iluminista até que ela seja por seu lado submergida pelo retorno do que tinha sido eliminado pelas burguesias pós-revolucionárias durante sua longa ocupação do poder.

A partir de qual momento esta desintegração da modernidade tornou-se completa e não mais parcial? Precisamente quando o universo da racionalidade instrumental separa-se completamente daquele dos atores sociais e culturais. Sexo, consumo, empresas e nações estavam então livres para evoluir livremente, à deriva, como icebergs quando se rompe o gelo movediço, distanciando-se uns dos outros, entrando em colisão, colando-se também às vezes provisoriamente um ao outro. Mais concretamente ainda, saímos da modernidade quando um comportamento ou forma de organização social não é mais definida de acordo com seu lugar num eixo tradição-modernidade ou subdesenvolvimento-desenvolvimento, como se diz mais freqüentemente para os países menos modernizados. Vivemos cada vez mais conscientemente, ao menos desde 1968, esta saída da modernidade. Os fatos sociais não são mais explicados por seu lugar numa história que teria um sentido, uma direção. $O$ pensamento social espontâneo, as ideologias e atmosfera da época (l'air du temps) abandonaram toda referência histórica. É isto sobretudo que significa o tema do pós-modernismo, que é antes de tudo pós-historicismo.

A esta crise da idéia clássica de modernidade, da ideologia modernista, duas respostas são possíveis: a primeira, aquela dos pós-modernos, afirma que sua decomposição é irreversível; a segunda, que a modernidade pode e deve ser defendida e mesmo alargada. É o que pensa Jürgen Habermas e é também, em termos diferentes, a idéia que eu defenderei na terceira parte deste ensaio. Mas, antes de seguir esta direção, é preciso ir em primeiro lugar até o fim da estrada que leva da idéia clássica da modernidade à sua crise, à sua decomposição e enfim ao seu desaparecimento.

Seguindo Alain Touraine (1992), pode-se dizer que a pós-modernidade tem quatro grandes eixos de pensamento, representando os diferentes tipos de rupturas com a ideologia modernista.

1) O primeiro define a pós-modernidade como uma hiper-modernidade, da mesma maneira que Daniel Bell definia a sociedade pós-industrial como hiper-industrial. O movimento de modernidade não cessa de se acelerar, os avantgardes tornam-se cada vez mais efêmeros e toda a produção cultural, diz justamente Jean-François Lyotard, torna-se avant-garde por um consumo cada vez mais rápido de linguagens e de signos. A modernidade se auto-suprime. Baudelaire definia a modernidade como a presença do eterno no instante, em oposição ao idealismo das culturas vinculadas a emanar as idéias eternas das deformações e das manchas da vida prática e dos sentimentos; um século mais tarde, no entanto, ela parece ser uma prisioneira do instante e acarreta na eliminação cada vez mais completa do sentido. Cultura caleidoscópica que não renuncia à modernidade, mas a reduz à construção de arranjos técnicos que não retém mais a atenção a 
não ser por sua novidade e suas proezas técnicas, rapidamente ultrapassadas.

2) Bem diferente - se bem que facilmente complementária - é a crítica, não mais do modernismo técnico, mas do modernismo social e político que inventou contra-modelos de sociedades cuja realização chamava a intervenção de um poder tanto mais absoluto quanto a ruptura a efetuar era mais completa. A idéia de revolução, eu já disse no começo, para sempre foi estreitamente associada àquela de modernidade. $\mathrm{O}$ sucesso intelectual do pós-modernismo foi, no fim dos anos 1970, um efeito direto da crise da esquerda revolucionária. O neo-liberalismo que triunfa na vida econômica e política no curso dos anos 1980 e o pós-modernismo cultural são os produtos paralelos da decomposição da esquerda. Esta foi uma forma extrema de modernismo, principalmente entre os trotskistas que, desde os começos da revolução soviética, cultivaram a utopia da máquina central, tornada plano central, transformada mais recentemente em computador central, com o papel de transformar o governo dos homens em administração das coisas e então liberálos dos delitos do subjetivismo político de tipo stalinista ou hitlerista. Na França, é Jean Baudrillard que cumpriu com maior determinação esta passagem da crítica esquerdista à crítica pós-modernista da esquerda, chegando mesmo à negação do social.

3) Estas duas aproximações, hiper-modernista e anti-modernista, podem sair completamente do campo da modernidade, mas pode ser em direções opostas. A mais freqüentemente confirmada é a ruptura com o historicismo, logo a substituição da sucessão das formas culturais pela sua simultaneidade. Uma obra carregada de significações religiosas e sociais por uma sociedade pouco diferenciada deve ser disposta, no nosso imaginário e nos nossos museus, lado a lado com um puro arranjo de formas, com a expressão di- reta de um sentimento; ou com uma obra carregada de um sentido comercial ou político. Não porque todas nos remeteriam a idéias eternas, mas porque nada permite escolher entre experiências que devem todas ser aceitas a partir do momento em que elas têm, diz Habermas, uma certa autenticidade. Este pluralismo cultural, este retorno ao politeísmo misturado com ateísmo, impulsiona ao extremo a idéia que Weber tinha tirado de Kant: se a modernidade repousa sobre a separação das essências e dos fenômenos, e se a ação técnica e científica se situa unicamente no segundo destes domínios, nosso espaço cultural e político é forçosamente politeísta, visto que a unicidade da explicação racional dos fenômenos é dissociada de um mundo de deuses que não tem de agora em diante nenhum princípio de unidade. O pós-modernismo torna-se aqui pós-historicismo, o que é seu sentido principal e que lhe dá sua importância.

4) Mas se as obras culturais são separadas do conjunto histórico onde apareceram, seu valor não pode mais ser definido a não ser pelo mercado. Daí a importância nova do mercado da arte enquanto que, durante muito tempo, as obras tinham sido escolhidas seja pelos príncipes, seja pelos amadores representando certas demandas culturais da aristocracia ou da burguesia. O que nos leva à nossa análise da sociedade liberal onde triunfam dois dos elementos da modernidade fragmentada, a empresa e o consumo, sobre os dois outros, Eros e a nação; uma vitória, portanto, do movimento e mudança sobre o Ser.

O movimento pós-modernista impulsiona assim ao extremo a destruição da representação modernista do mundo. Ele rejeita a diferenciação funcional entre os domínios da vida social - arte, economia, política - e seu complemento, o uso por cada um deles da razão instrumental. Assim fazendo, ele recusa a separação entre a alta cultu- 
ra, social e política assim como estética, que se refere a garantias metasociais da ordem social - a razão, a história, a modernização ou a liberação da classe operária - e a cultura de massa. Daí sua palavra de ordem "anti-estético" fortemente sublinhada por Frédéric Jameson (em particular no seu livro dirigido por Hal Foster (1983), The AntiAesthetic). Mais profundamente ainda, o que é rejeitado é a construção de imagens do mundo, para retomar o termo que Heidegger considera como o mais significativo da modernidade. $\mathrm{O}$ pensamento pós-moderno não aceita mais colocar o homem diante do mundo, olhando-o, reproduzindo-o em imagens, pois ele coloca o homem no mundo, sem distância, ou melhor, substituindo esta distância que supõe a existência prévia do objeto pela construção de uma rede de comunicações, de uma linguagem entre o pintor, o arquiteto ou o escritor e os objetos.

Esta evocação de um novo sistema de ação histórica, aquele da sociedade programada, com seus atores, seus movimentos sociais, as dimensões culturais de seus conflitos e de suas negociações, está muito distanciada das imagens hoje dominantes de nossa sociedade, aquelas que são associadas à idéia de pós-modernismo. O que me conduz a definir o que opõe esta idéia àquela de sociedade pós-industrial ou programada. O pósmodernismo afirma a dissociação completa do sistema e do ator: o sistema é auto-referencial, autopoiétique, diz Luhman, enquanto que os atores não se definem mais pelas relações sociais, mas por uma diferença cultural. Não nego que estas afirmações correspondam a uma parte da realidade, mas elas são tão deformantes quanto as descrições, no início do século XIX, da sociedade industrial como o reino do dinheiro e da mercadoria. O que não era ainda a classe operária era representada como o mundo diferente ou sublime dos subúrbios (faubourgs), dos ateliers e dos bares de última categoria (assommoirs); na sociedade capitalista, o mundo do dinheiro e aquele do trabalho pareciam estrangeiros um ao outro. Foi necessário esperar os sindicatos e as idéias socialistas para descobrir, atrás destas diferenças extremas, as relações de produção. A sociedade contemporânea possui um tal grau de controle sobre si mesma e sobre sua historicidade que realmente existe a possibilidade de uma ruptura cultural que não deixa mais espaço para o conflito social. Mas a evolução inversa é mais provável. Falamnos de nossa sociedade como uma sociedade da informação, da mesma maneira que costumava ser descrita como sociedade industrial ou idade da máquina. Quanto tempo será necessário ainda para que se reencontrem seres humanos e relações sociais atrás das técnicas e que se compreenda que em todos os lugares confrontam-se maneiras socialmente opostas de utilizar a informação e de organizar a comunicação, seja "abstratamente" para reforçar os fluxos de informação que são também fluxos de dinheiro e de poder, seja "concretamente", para reforçar o diálogo entre os atores situados desigualmente nas relações de poder ou de autoridade?

Vejo antes de tudo nas idéias pós-modernas uma interpretação sociologicamente superficial de transformações, as quais, de fato, pedem análises mais próximas, não radicalmente diferentes daquelas empregadas para a sociedade industrial. Nos fenômenos sobre os quais insiste o pensamento pós-moderno, vejo mais situações de crise do que inovações duráveis. A extrema diferenciação do sistema político e do sistema social, do qual fala Luhman, não define a crise de representação política que cada um reconhece e que somente será vencida no dia em que novas demandas sociais serão organizadas e em que nossas democracias serão tornadas representativas? Da mesma maneira, o apelo à diferença ab- 
soluta é somente uma conduta de crise quando ela se separa do reconhecimento dos conflitos sociais e de suas dimensões culturais.

Vivemos a passagem de uma sociedade a outra. O século XIX foi quase todo ocupado pela passagem de uma sociedade mercantil a uma sociedade industrial e do espírito republicano ao movimento operário. Luhman lembra com muito justeza que uma sociedade não pode ser definida por uma só destas dimensões: industrial, capitalista ou democrática. É verdade hoje, mas o era também no passado.

O interesse principal deste debate é de lembrar que a idéia de sujeito é inseparável da idéia de relações sociais. Na sociedade programada, o indivíduo, reduzido a ser apenas um consumidor, um recurso humano ou um alvo, se opõe à lógica dominante do sistema afirmando-se como sujeito, contra o mundo das coisas e contra a objetivação de suas necessidades em demandas mercantis. É por isso que a idéia de sujeito não é separável de uma análise da sociedade presente, não como pós-moderna mas como pós-industrial ou programada. As teorias pós-modernas nos mostram a decomposição do sujeito, mas também as demandas crescentes das minorias tanto quanto o desenvolvimento dos sistemas cibernéticos. Mas, no lugar de apenas captar o estranhamento recíproco destes dois mundos, por que não ver seu conflito, pois nenhum dos dois se define em si mesmo, tecnologicamente ou culturalmente; um e outro devem ser definidos socialmente, mais precisamente por sua mútua oposição.

\section{III}

E havia Lyotard... Lyotard foi o primeiro a chamar "pós-moderna" a crise intelectual causada pela filosofia. O que quer dizer para ele esta palavra mágica? Em A Condição Pós-moderna, seu texto mais lido e, provavelmente, o menos compreendido pelo que é (uma relação sociológica e não uma análise filosófica), encontra-se mais ou menos isto: como a filosofia não pode mais legitimar a pragmática dos discursos político, jurídico, das ciências naturais e das artes - o vocabulário analítico da virada lingüística que Lyotard emprega aqui é sintomático desta crise da legitimidade que finalmente é uma crise do pensamento metafísico do tipo platônico e cartesiano - ela provoca uma crise intelectual desorientando todos os setores da atividade humana. Agora a questão é de saber onde encontrar a legitimidade.

Em Jean-François Lyotard, a elaboração da noção de pós-moderno começa como uma retomada do que se chama, na teoria crítica da Escola de Frankfurt, a dialética do iluminismo. Ela partilha então os defeitos de todas as teorias que organizam o maniqueísmo lógico da razão e de seu Outro. Com efeito, a dialética do iluminismo joga com um par de conceitos: a razão e o mito.

A pós-modernidade indentifica-se para ele com um estado de crise generalizada da legitimidade dos saberes, com a desestabilização dos grandes determinismos. Ele distinguia dois modelos teóricos dominantes até uma data recente, um orgânico e outro dialético, a sociologia funcional, ou ainda a teoria dos sistemas, e o marxismo. Mas estes modelos cruzaram-se e neutralizaram-se mutuamente, a luta de classes tornando-se um princípio de regulação integrado ao capitalismo liberal, enquanto que em nome do marxismo, as sociedades comunistas tendiam ao abafamento das diferenças. A grande narrativa da emancipação da humanidade e da conquista da liberdade perdeu sua virtude de unificação e de legitimação: era o discurso do progresso e das Luzes desenvolvido desde o século XVIII. A pós-modernidade, para além de seus aspectos estéticos, reexamina o pensamento iluminista sem aceitar a idéia 
de um fim unitário da história, ela coloca em questão o ideal moderno de razão em seus efeitos desastrosos, inclusive o nazismo.

Lyotard não hesita em recorrer à narrativa mais ortodoxa da tradição moderna para explicar a ambivalência inerente ao pós-moderno. Ele escreve em 1982: “O que é então o pós-moderno? Que lugar ocupa ou não ocupa no trabalho vertiginoso das questões lançadas às regras da imagem e da narrativa? Ele faz seguramente parte do moderno. Tudo que é recebido do passado, mesmo se apenas de ontem (modo, modo, escrevia Pétrone), deve levantar suspeitas. Qual espaço Cézanne aborda? Aquele dos Impressionistas. Qual objeto Picasso e Braque abordam? Aquele de Cézanne. Com qual pressuposto Duchamp rompe em 1912? Aquele de que é preciso fazer um quadro, mesmo cubista. E Buren interroga este outro pressuposto que ele estima sair intacto da obra de Duchamp: o lugar da apresentação da obra. Espantosa aceleração, as 'gerações' se precipitam. Uma obra somente pode tornar-se moderna se ela é em primeiro lugar pós-moderna. $\mathrm{O}$ pós-modernismo assim compreendido não é o modernismo em seu fim, mas o estado nascente, e este estado é recorrente". Lyotard (1982) acrescenta, algumas linhas mais adiante, que ele não estará satisfeito com esta "aceitação um pouco mecanicista da palavra", é demasiado tê-la sugerido, pois aí se encontra, sem a menor distância, o dogma da evolução. Lyotard vai mais longe. Se a modernidade, escreve, é o refúgio do realismo, na tensão do apresentável e do concebível, então “o pós-moderno seria o que no moderno propõe o inapresentável na apresentação ela-mesma; o que recusa à consolação as boas formas...". "...Pósmoderno teria que ser compreendido segundo o paradoxo do futuro (post) anterior (modo). Parece-me que o ensaio (Montaigne) é pós-moderno, e o fragmento (Athaeneum) moderno". O pósmoderno concebe-se como a verdade do moderno, como a realização das possibilidades ainda não realizadas no moderno, e portanto como uma ultrapassagem a mais em direção à essência da arte.

\section{* * *}

A filosofia pós-moderna respeita a incomensurabilidade dos jogos, impede a usurpação ou o excesso de um sobre o outro, mantendo a boa distância, o "abismo" que existe entre cada um dos jogos de linguagem. Esta preocupação não se inspira somente em Wittgenstein mas, mais claramente ainda, em Kant. É aquela da "crítica" kantiana como juiz de um "tribunal" que governa sobre "o território", "o domínio" onde são validadas frases ou jogos de linguagem. Em um outro sentido: "Ser justo é se aventurar a fazer uma hipótese sobre o que há a fazer". Esta "hipótese" implica "uma idéia e uma prática da justiça que não é aquela do consenso" (Lyotard, 1979). Ela chama em conseqüência uma "política do julgamento" (Lyotard, Thébaud, 1979) cuja indicação fecha $A$ condição pós-moderna. Esta política implica em que a infinidade da história, do tempo e da Idéia devem ser julgadas de acordo com a "imaginação dos efeitos" (Lyotard, Thébaud, 1979), em resumo o "julgamento precede todas as regras" (Lyotard, 1981). Nestas condições, o ato de julgar é uma faculdade política e não somente jurídica. E é toda a problemática kantiana que é reexaminada por Lyotard.

O sentimento do sublime pertence já para ele à pós-modernidade da qual ele é um dos primeiros a descrever os traços (Lyotard, 1979). Na condição pós-moderna, o sentimento do sublime se substitui ao julgamento de gosto. A experiência, no sentido hegeliano, cede lugar à experimen- 
tação. O artista e o filósofo, irmãos em experimentação, inventam usando palavras, cores, sons, ou frases e suas regras de formação. Ambas "jogam" com um desprazer combinado com satisfação, com o esforço de apresentar o inapresentável e o ilimitado do pensamento. A pintura hoje apresenta somente o invisível, jamais a realidade aceita ou a ausência de realidade: há, diz Lyotard, o "inapresentável" para o pensamento (o absoluto, o infinito etc.). Os estudos que ele consagrou ao trabalho de artistas contemporâneos mostram o quanto o fim da experiência, a questão do tempo estão no coração da pintura pós-moderna como no coração do capitalismo (Lyotard, 1984): o pintor pós-moderno pinta monochrome ou, pela cor, ao contrário, "constitui o tempo". A estética do sublime conflita sem cessar com o que, de perto ou de longe, se exige do real, do realismo, da realidade. O assujeitamento do pensamento a outros fins que a si próprio, a uma suposta finalidade única e unitária da história ou do sujeito, a um dado presente ou futuro, é abundante da ameaça do Terror. Nenhum dos participantes na confrontação (agôn) de frases e jogos de linguagem, está autorizado a infligir um certo "golpe": aquele que "faz um uso mesmo indireto mesmo simbólico da ameaça da morte à intenção de seus destinatários" (Lyotard, 1973). Pertence sem dúvida à condição pós-moderna que o pensar seja um "frasear". Pensar é apresentar e encadear frases. É pesquisar a regra "sem que se possa anunciar o que diz esta regra" (Lyotard, 1981). É também marcar a incomensurabilidade das frases, "o abismo" que as separa e tomar partido na "disputa". Uma ontologia se esboça: não mais "ser-no-mundo" dos fenomenólogos, mas "ser-com as frases [que] não é um ser-como, nem um ser-conjunto, tampouco um ser-sem" (Lyotard, 1981).
IV

Ecologia e modernidade. A onda de movimentos ecológicos não pára de crescer no mundo. Observa-se o desenvolvimento extraordinário da preocupação de autenticidade, da preocupação de si, que acompanhou o desaparecimento das ideologias políticas fortes. Fato marcante: o movimento ecológico é o primeiro movimento político a considerar que o medo do futuro, sobretudo aquele de não poder voltar atrás, é um dever. Paralelamente aparece a tomada de consciência do caráter planetário dos problemas de meio ambiente, do efeito estufa, das catástrofes atômicas, da poluição.

Mas a ecologia não constitui um movimento homogêneo. Ela é divisível em três grandes correntes, que têm em comum a crítica da modernidade. A corrente de direita (mesmo de extrema direita) que se reclama um passado perdido: o mito quase romântico da idade de ouro, da diversidade cultural, da sociedade rural (terroir), do homem vivendo em harmonia com a natureza. Em seus discursos eles jogam sobre um registro ambíguo falando de materiais "apátridas", que não se integram então no quadro natural. Inconscientemente, eles valorizam o pertencimento nacional. Certos temas similares são integrados na ideologia da segunda corrente, aquela da extrema esquerda, que dominou na França nos anos 1960, exemplificada pelo Partido Socialista Unificado PSU. Eles reivindicam inspiração em Félix Guattari e em seu livro As três ecologias (1989). Face a este universo capitalista, unidimensional, universalizante, já denunciado por Marcuse (1964), é preciso resingularizar os indivíduos e os modos de vida. Esta constatação vai ainda mais longe; as agressões ao meio ambiente são o produto da economia de mercado e da sociedade liberal, 
portanto da democracia da qual elas são oriundas. Os ecologistas de extrema direita e de extrema esquerda constatam mais ou menos explicitamente os fundamentos da sociedade ocidental. Eles não centram suas reflexões em torno do homem com um $\mathrm{H}$ maiúsculo, o homem da Declaração dos direitos do homem, mas em torno do indivíduo concreto, situado (localizado), tal como o Bretão, o Corso, mas também as mulheres, os Negros, os imigrantes, mesmo a própria natureza. Mesmo Michel Serres, retomando as teses desenvolvidas nos Estados Unidos pelos deep ecologists, defende a idéia de que a natureza (as florestas, os vales, os animais etc.) tem direitos, da mesma maneira que o homem. Uma passagem está se instituindo, do antropocentrismo a uma visão ecocentrista do mundo. Quando Michel Serres (1990) escreve que o contrato natural substitui o contrato social, ele propõe terminar com a tradição humanista segundo a qual o homem é o único sujeito do direito, para chegar à idéia de que a própria natureza pode ser considerada como um parceiro num contrato, que ela pode ser sujeito do direito. Estes ecologistas não propõem nem uma política coerente, nem um modelo. Há somente uma idéia central: é preciso parar a todo custo a evolução atual. Nos anos 1970 na Alemanha, Hans Jonas (1990) em O princípio de responsabilidade sustentou a idéia de que a democracia liberal é incapaz de controlar a técnica, fonte de todos os males, e que seria preciso passar por um controle autoritário. Outros crêem ainda no fantasma da autogestão, de Dany CohnBendit à Cornelius Castoriadis e Félix Guattari.

A terceira corrente na nebulosa ecologista faz uma crítica interna da democracia, e advoga utilizar a ciência para opor-se diretamente aos efeitos negativos da ciência e da técnica. A democracia deve integrar a ecologia a todos os níveis de decisão. Seu discurso político é mudo e recoberto pelos elementos de duas outras correntes. De maneira geral, esta sensibilidade ecologista não coloca em questão os benefícios do Estadoprovidência. Critica-se o mundo industrial mas não se está pronto a renunciar a tomar o avião, a se curar, a comunicar, enfim, a tudo o que traz o universo técnico. Daí o caráter complexo desta tendência, porque ela contém muitos elementos disparatados, a modernidade e a pós-modernidade.

As sociedades industriais conhecem uma crise. A ecologia é em todos os casos uma reação a esta crise. A prova é que as reivindicações ecológicas somente aparecem em tais sociedades. A ecologia é, sob todas as formas, a expressão de um sentimento de vazio próprio ao Ocidente democrático, liberal, produtivista. Quais são as fontes deste sentimento? Ele provém desta "melancolia democrática" descrita pelo filósofo Pascal Bruckner, ligada ao desabamento dos totalitarismos que deixam as democracias sem inimigos? Do declínio das ideologias fortes que forneciam ideais exaltantes? Da ausência de um grande desígnio? De uma nova forma intensificada de individualismo? Do declínio das religiões tradicionais e "religiões seculares" (ou seja, políticas)? O que quer que seja, se a ecologia em geral é resposta ao sentimento do vazio, cada corrente faz sua própria crítica da modernidade.

\section{V}

Espaço, lugar, não-lugar, hipermodernidade, globalização, ... numerosas reflexões se foram em explicar, freqüentemente de uma maneira bastante técnica, a transformação contemporânea dos lugares; uma modernidade impele ao extremo, em direção a uma hipermodernidade ou su- 
permodernidade. Uma viagem para além do moderno, para além dos lugares.

O espaço se apreende enquanto categoria e realidade material. Os filósofos o tratam como um princípio do entendimento de uma das formas do conhecimento, de uma ferramenta da produção teórica ao mesmo nível que o tempo, ao qual está ligado. Os sociólogos o consideram sob o duplo aspecto de um produto da sociedade e de um produtor social. Em sua relação com o espaço, por seu trabalho presente e aquele das gerações anteriores, o homem cria lugares. Os antropólogos centraram sua atenção sobre os espaços mais qualificados, conferindo-lhes uma tripla função: identitário, relacional e histórico. A supermodernidade, em sua relação ativa com o espaço, pode ser vislumbrada sob três aspectos quanto a seus efeitos mais significativos: a desqualificação, a desrealização e a virtualização. A desrealização corresponde à mobilidade, às redes, a um "contraespaço"; a virtualização introduz uma ruptura, ela confunde a distinção entre o real e o real virtual, é o universo da televirtualidade. A desqualificação designa os espaços de pouca especificidade. Os não-lugares ilustram o contra-tipo do lugar antropológico, apresentado por Marc Augé (1992). Os não-lugares acumulam a característica de ser aqueles onde as pessoas simplesmente passam e de requerer de seus usuários condutas que pode-se dizer mecânicas, reduzindo os indivíduos ao status de operadores.

O que é uma geografia de lugar nenhum? Certamente o contrário de alguma parte, então de um lugar ou ainda melhor de um meio. Podese ler também "meio-lugar" (em francês, "milieu"), ou seja, meio lugar, meio não-lugar. Um espaço onde não são simbolizados nem identidade, nem relação, nem história: os aeroportos, as rodovias, os quartos de hotel intercambiáveis, os meios de transporte... É a primeira vez na his- tória do planeta que os não-lugares (ou os meiolugares) ocupam tanto espaço. Não se trata de opor um bom lugar, humano, a um mau lugar, desumanizado. Viver numa pequena aldeia onde todo mundo o observa não é sempre agradável. O lugar tem às vezes demasiada alma. Esta alta forma o meio. Pode ser terrorista. Inversamente, o não-lugar não é sempre desagradável. Esperar seu avião sonhando, sem ser interrompido por ninguém, pode comunicar um sentimento de paz.

No lugar há o sentido, mas também a nãoliberdade, a coação. No não-lugar, por sua vez, há uma liberdade individual que pode ir até o absurdo e a perda de identidade. Quando um nacionalista fala do cosmopolitismo, ele invoca os lugares contra os não-lugares, isto é, contra os espaços de mistura. Dito isto, os não-lugares podem ocorrer em contextos inapropriados. Os vendedores em uma loja de departamentos ou os frentistas num posto de gasolina são também elementos do contato social cotidiano. Assim como as pessoas preferem ir ao bistrô ao invés de tomar seu café diante de um distribuidor automático!

A segunda metade do século XX nos ofereceu estes (ou seus) espaços. A velocidade, os transportes (Virilio, 1993, 1995), a mundialização das trocas, da circulação, do consumo engendram a fabricação dos lugares intercambiáveis, idênticos em toda parte no mundo, onde se passa sem parar, sem encontrar ninguém. Os exemplos são numerosos: rodovias, pedágios, enormes estacionamentos, aeroportos, distribuidores automáticos (dinheiro, bebida, bilhetes etc.), shopping centers, supermercados, cadeias de distribuição e de marcas (Benetton, Lacoste, Hugo Boss, Ralph Lauren etc.), cadeias de hotelaria e de restaurantes (Novotel, Hilton, MacDonalds etc.) ... Num aeroporto, num hipermercado, as pessoas passam umas perto das outras sem nenhuma necessida- 
de de relação. Um novo Jules Verne não escreveria "A volta ao mundo em oitenta dias" - seria necessário verdadeiramente que o viajante diminuísse a velocidade - mas sim "A volta ao mundo sem uma palavra". Poder-se-ia fazer uma aposta em que seu herói tivesse setenta e duas horas e fizesse a volta ao mundo sem pronunciar uma palavra. Ao preço de um sorriso ou de algumas grosserias.

A lógica econômica não escapa mais à lógica de "parte nenhuma". As empresas utilizam também estes espaços sem histórias (em todos os sentidos do termo). As periferias longínquas atraem as empresas pelas vantagens econômicas (abatimento de taxas, regulamentações flexíveis para a utilização do solo). Hoje elas se deslocam para além das redes de transporte coletivo em direção às zonas chamadas "Nowheresville": as cidades de parte nenhuma. Este fenômeno é descrito por Garreau em 1992, (citado por Galletti, 1992) em sua obra sobre os deslocamentos de empresas em direção ao que ele chama de "nenhuma parte". Estas "nenhuma parte" chamam-se, por exemplo, " $287 / 78$ ", uma zona que está a uma hora a oeste de Wall Street num lugar levemente arborizado de Nova Jersey. Estas "nenhuma parte" obtiveram sua identidade das rodovias interestaduais 287 e 78 que se cruzam neste lugar. Estas conexões rodoviárias encorajaram algumas das grandes empresas americanas a abandonar os inconvenientes do centro (preço fundiário, estorvos e outras deseconomias) por espaços mais vastos recentemente criados. Por exemplo a zona "287/ $78^{\prime \prime}$ possui mais edifícios que o centro de Nova Orléans. Acha-se aí a Johnson \& Johnson, AT\&T, Bristol Myers entre outras. Jorôme Galletti em seu relatório de 1992 mostra que a força destes espaços é a resposta às necessidades do carro, do jet e do computador. Então o que cria estas Edge Cities (cidades de fronteira, de margem) é a função e não a imagem visual do centro da cidade bem definido e de edifícios mais altos. Tem-se a impressão de que a "nenhuma parte" tem uma conotação de um funcionalismo extremo.

Há também nossa maneira de olhar o mundo. Assim, o consumo turístico é freqüentemente um olhar abstrato, desatento aos outros. As mesmas pessoas que contam com júbilo suas lembranças de Marrakech, escandalizam-se de supostas dificuldades que criariam os magrebinos em periferias que eles não habitam! Assim como, o jogo das imagens nos dá a ilusão de uma familiaridade com o Texas ou o Curdistão. Outros exemplos desta relação ilusória ao lugar: os pequenos letreiros das rodovias que lhe indicam o que você veria se parasse. Em realidade, você não pára, mas você vê desfilar os letreiros indicando "Vézelay, colina eterna", "Cidade fortificada do século XII". Assistimos a uma espetacularização do mundo.

Vivemos uma época sem precedente. Tudo se mexe. A crença nos dogmas das religiões tradicionais é revolucionada, partidos e sindicatos estão em crise. A adesão a valores costumava ordenar o cotidiano. O militante não é necessariamente aquele que discute a ideologia todos os dias, não mais do que o católico que não se questiona quotidianamente sobre o sentido da presença real de Deus, mas suas práticas davam sentido à vida social. Entre a individualização absoluta de um lado e a mundialização de outro, há buracos na camada ideológica.

Os excessos de espaço, de tempo, de eventos, de informações, têm conseqüências. Há cincoenta ou cem anos, não tínhamos todos os dias o sentimento de estar na história. Hoje, a rádio, a televisão dão a impressão de que eventos historicamente importantes ocorrem diariamente. A história parece estar em nossos calcanhares. Instala-se uma confusão entre a história e a atualidade. Estes três excessos, de tempo, de espaço, 
de eventos dão o sentimento de uma perda de sentido. Ora, o que é novo, não é que o mundo tenha pouco ou nenhum sentido, mas sim que deveríamos sentir a constante necessidade de darlhe um (significado). Outrora, em sua aldeia, o sentido existia por si mesmo. Hoje, somos convidados a dar um sentido a tudo, do terrorismo no Peru ao islamismo na Argélia.

Estamos em uma situação de comunicação solitária, como parece exprimir a multiplicação dos não-lugares. A simples coexistência de indivíduos não é mais possível. A ligação social se recompõe necessariamente. Resta a saber em quais condições. O risco existe de procurar princípios de identidade simplistas, como a reivindicação de indentidade étnica, a fabricação do estrangeiro, o fascismo. Mas pode-se também, e deste ponto de vista a questão da Europa é muito importante, adicionar a progressão dos direitos do indivíduo, a responsabilização crescente de cada um. Refundar alguma coisa na França ou na Europa implica em não falar em termos simples de identidade nacional mas falar de relação ao outro. $\mathrm{O}$ mundo muda. O outro interessa menos, ou então desconfia-se. Por que a imigração é vista logo de cara sob seu ângulo problemático? É admitir a idéia de outros mais outros que os outros, os estrangeiros. Fabricar o estrangeiro porque não se sabe mais pensar o outro atesta uma patologia social. O estatuto dos estrangeiros na França, daqueles que desejam continuar estrangeiros e aqueles que não, é uma questão central. Uma questão que resolvemos bem em nossa história mas sobre a qual existe uma verdadeira clivagem política. Não é o caso de que há um consenso do qual a extrema direita é a única exceção. Hoje, pensa-se o caráter estrangeiro do outro, não se pensa sua alteridade. Pensar a alteridade é também pensar a identidade, a relação, a ligação. Criamos cate- gorias de exclusão enquanto somos feitos para viver uns com os outros.

Uma verdadeira revolução se produz ao nível da vida quotidiana. Os lares tornaram-se auto-suficientes para a informação, para a imagem e o som. Esta situação tem duas conseqüências relacionadas: uma abertura planetária recebendo a informação sobre o mundo inteiro à velocidade da luz, e ao mesmo tempo um isolamento pessoal e a individualização das experiências de comunicações; chamarei este fenômeno a comunicação solitária. O habitat se desintegra da vida e do espaço urbano sem por isso se isolar. As pessoas vivem no mesmo momento o mesmo evento, retransmitido pela $\mathrm{CNN}$ ou por outras cadeias de televisão, a várias dezenas de milhares de quilômetros de distância, sentadas no mesmo modelo de poltrona fabricada pela IKEA, no mesmo tipo de quarto concebido por Holliday Inn, comendo o hambúrguer fornecido pela MacDonalds. Os lugares e o meio não têm a menor significação.

O geógrafo sempre foi concernido por pelo menos dois espaços: aquele do lugar que ele estuda (uma região, uma cidade etc.) e aquele, mais vasto, onde este lugar se inscreve e de onde operam as influências e coações que têm conseqüências para a estrutura interna das relações locais. O geógrafo está assim condenado ao estrabismo metodológico: ele deve manter um olho no lugar imediato de sua observação, e o outro nas fronteiras de sua influência externa. Neste mundo pós-moderno, uma parte deste exterior é feita de não-lugar e uma parte destes não-lugares de imagens. A freqüentação dos não-lugares, hoje, é a ocasião de uma experiência sem verdadeiro precedente histórico de individualidade solitária e de mediação não humana entre indivíduo e poder público. O geógrafo das sociedades contem- 
porâneas encontra então a presença individual no universo englobante onde ele estava tradicionalmente habituado a orientar os determinantes gerais que davam sentido às configurações particulares ou aos acidentes singulares.

No mundo "hipermoderno" ou "supermoderno" se está sempre e não se está nunca mais "em casa", as zonas de fronteiras não introduzem mais a mundos totalmente estranhos. A hipermodernidade, - que procede simultaneamente das três figuras do excesso que são a superabundância de eventos, a superabundância espacial e a individualização das referências - encontra naturalmente sua expressão completa nos não-lugares.

Não há mais análise social que possa fazer a economia dos indivíduos, nem análise dos indivíduos que possa ignorar os espaços por onde eles transitam.

Há pois lugar, talvez desde agora, apesar da contradição aparente dos termos, para uma geografia de nenhuma parte ou uma geografia dos não-lugares, fora-dos-lugares ou ao menos meio-lugares.

Mas sob o efeito do tempo, os não-lugares não permanecem assim inteiramente. Eles se inscrevem numa paisagem social antiga e maior. Eles acabam por forjar os hábitos. Eles estão submetidos, eles também, a este trabalho que Michel de Certeau (1980) qualificou de "invenção do quotidiano", e por isto adquirem alguma qualidade. O que conduz a reconhecer duas das formas da reapropriação do espaço, atual mas em relativa continuidade com as práticas passadas: a constituição progressiva, lenta, dos não-lugares em lugares ainda mais qualificados, a revalorização dos lugares banais por uma melhor integração destes que, mais antigos, carregados de significações e classificados, são instituídos como lugares de memória.
VI

É preciso concluir? É certo que nenhuma conclusão definitiva pode ser alcançada. No entanto, certas idéias aparecem com força, no plano do método e no avanço do debate. Temos a chance de ter vivido, de viver hoje uma crise espetacular do mundo intelectual, uma revisão dos fundamentos teóricos de toda a orientação moderna do pensamento. Se, por um lado, o termo de pós-modernidade aparece já como um dos gritos de adesão dos anos 1980 e 1990, por outro é muito difícil prever seu futuro. Pode-se certamente apostar em seu declínio. Mas fenômenos tão pouco prováveis quanto... a lentidão de circulação das idéias, assegura-lhe ressurgências imprevistas, na forma de uma falsa inovação ou uma sobrevida enigmática.

O pós-moderno aparece como um significante livre, paradoxal porque essencialmente imaginário ou se se prefere como uma ficção conceitual, uma categoria que é da ordem do como se... Tudo se passa como se o futuro tivesse se tornado um lugar vazio... Façamos como se a modernidade estivesse terminada... Para ver!...

Nem voluntarista nem ativista a abordagem pós-moderna é mais bem uma paixão a "tecer alteridades", das quais ela projetaria as arestas. O modelo da modernidade seria somente um traço insistente. Por isso construção, desconstrução e reconstrução seriam condensadas em um mesmo gesto. Vê-se bem que o pensamento pós-moderno corre o risco de ser assimilado a um metadiscurso em seu projeto mesmo de aproximar o vivo da experiência. De fato, ela vive esta oscilação: ela é então uma forma que tem valor de índice, "sismográfica", apta a se abrir ao empirismo da sensibilidade estética e social. Em seus avanços como em seus impasses, ela já destrói a 
autoridade do ato pelo qual a racionalização dos discursos invalida o que se passa no mundo real. A modernidade que forneceu o contexto para o seu desenvolvimento não é negada mas é modificada para que a liberdade, que em seu tempo tinha permitido a criatividade, seja preservada.

A questão é de saber se é possível e como é possível pensar e introduzir a mudança. Como se estivéssemos confrontados pela primeira vez com um verdadeiro problema prático: somos os autores do que muda, mas esta mudança é tão rápida que podemos de agora em diante, por uma volta à história imediata, discernir e discutir as decisões que, acumuladas, modificam a economia. Esta história próxima, tornada crítica permanente do presente, nos livra definitivamente das ilusões da tabula rasa. Tudo que temos a fazer é observar e imaginar o estado seguinte do mundo, depois perguntar-nos se é isto que queremos, sabendo que, somente iniciadas, as transformações que projetamos modificam já os termos deste querer. Na retirada simbólica da história inaugura-se uma estranha circularidade do desejo e da praxis. Contando sua própria odisséia, inventando-a no dia a dia, a humanidade pós-moderna espera ser capaz de delinear os significados. E se se trata de um efeito de logro, este logro constitui em si uma questão.

\section{$* * *$}

Uma das grandes questões de nossa disciplina atualmente é: como tomar a medida da relação complexa entre os movimentos que agitaram, e agitam, a geografia e os assédios da modernidade. São as sereias do pós-modernismo que suscitam em muitos geógrafos um tal abandono na pesquisa de quadros teóricos gerais? O que quer que seja, parece haver pouca dúvida de que o pensamento geográfico tenha inflamado tanto o modernismo, com a "revolução quantitativa", como o pós-modernismo, com o fragmentação das teorias ou a preocupação pluralista. Conhece-se a promessa de felicidade que fazia o modernismo por seu recurso a uma autonomização das esferas da ciência, da moral e da arte, na espera de uma síntese superior sempre adiada para mais tarde. Cada vez menos as pessoas acreditam nisso; é o fim dos consensos fortes em torno de algumas idéias mobilisadoras. A Razão bate em retirada e a ciência está em crise. Mas tratase, de fato, de uma ciência positivista que se coloca contra a narrativa. Mesmo em seus aspectos aparentemente mais racionais ou formalizados, as ciências sociais repousam sobre um certo número de mitos fundadores (Claval, 1980), retraçáveis em algumas grandes Narrativas. A geografia, à maneira de outras ciências, é de natureza narrativa (Berdoulay, 1988). O pluralismo do discurso geográfico se impõe então, e está aí um desafio da análise epistemológica pois as formas do discurso e o sentido entretêm relações múltiplas e não unívocas. A esta conclusão de estilo "pósmoderno" faz eco uma visão análoga do que se passa na sociedade: atomização dos indivíduos e retirada para solidariedades flutuantes e circunstanciais. Ao nível das práticas geográficas, isto é traduzido pelo retorno ao local, aos jogos de linguagem - como escrevia Lyotard - e pois uma valorização da pluralidade dos lugares. Mas então, se está no direito de se inquietar - como fazia Habermas - sobre o perigo de um poder que se exerceria sem freio num tal contexto de aparente descentralização. É toda a questão da democracia que está em jogo. O pensamento geográfico encontra-se interpelado por sua vez. Os geógrafos devem então redescobrir as ligações entre os lugares e as práticas democráticas: tanto uns como outras, ao nível científico como no quotidiano, não poderão escapar aos jogos do discurso: moderno ou pós-moderno, é a questão - ao menos deste manuscrito. 


\section{BIBLIOGRAFIA}

AMIN, A. Post-Fordism. Oxford, Blackwell, 1994.

ASCHCROFT, B.; GRIFFITHS, G. ; TIFFIN, H. (eds), The PostColonial Studies Reader. London, Routledge, 1994.

AUGE, M. Non-lieux. Introduction à une anthropologie de la surmodernité. Paris, Seuil, 1992.

BECK, U. Risk Society: Towards a New Modernity. London, Sage, 1992.

BELL, D. The Coming of Post Industrial Society. A Venture in Social Forecasting. New York, Basic Books, 1973.

BENKO, G. B. Géographie des technopóples. Paris, Masson, 1991.

BERDOULAY, V. Des mots et des lieux. La dynamique du discours géographique. Paris, Ed. Du CNRS, 1988.

BONDI, I. Feminism, postmodernism, and geography: space for women? Antipode, v. 22, n. 2, p. 156-167, 1990.

BONNETT, A. Situationism, geography, and poststructuralism. Environment and Planning D: Society and Space, 7, 2, p. 131-46, 1989.

. Art, ideology, and everyday space: subversive tendencies from Dada to postmodernism. Environment and Planning D: Society and Space, v. 10, n. 1, p. 69-86, 1992.

CLAVAL, P. Les mythes fondateurs des sciences sociales. Paris, PUF, 1980.

D'AGOSTINO, P. ; TAFLER, D. (eds). Transmission. Toward a Post-Telerision Culture, London, Sage, $\left(2^{\text {nd }}\right.$ ed.) $), 1994$.

DEAR, M. J. Postmodernism and planning. Environment and Planning D: Society and Space, v. 4, n. 3, p. 367-84, 1986.

. The premature demise of postmodern urbanism. Cultural Anthropology, n. 6, p. 538-52, 1991.

DEWS, P. Logics of Disintegration. Post-Structuralist Thought and the Clains of Critical Theory. London, Verso, 1987.

ECO, U. Apostille au 'Nom de la rose'. Paris, Grasset - Le Livre de Poche, 1985.

ESCOBAR, A. Imagining a post-development era? Critical thought, development and social movements. Social Text, n. 31/32, p. 20-56, 1992.

FEIJÖ, F. La fin de démocraties populaires. Les chemins du postcommunism. Paris, Seuil, 1992.

FERRY, L. Le nouvel ordre écologique. Paris, Grasset, 1992.

FEYRABEND, P. Contre le méthode. Esquisse d'une théorie anarchiste de la connaissance. Paris, Seuill, 1979.

FOSTER, H., (ed.). The Anti-Aesthetic. Esseys on Post-Modern Culture. Seattle, B. Press, 1983.
FOUGEYROLlas, P. Vers la Nouvelle Pensée. Essai postphilosophique. Paris, L'Harmattan, 1994.

FOX, C. J. ; MILLER, H. T. Postmodern Public Administration. London, Sage, 1995.

GALLETTI, J.C. Aux lieux du bureaux. Paris, Ed. Ministère de l'Equipement, 1992.

GRAY, J. Post-liberalism.Studies in Political Thought. London, Routledge, 1993.

HABERMAS, J. Modernity versus postmodernity. New German Critique, n. 22, p. 314, 1981.

The Philosophical Discourse of Modernity. Cambridge, Polity Press, 1985.

HARASYM, S. (ed.). The Post-Colonial Critic. London, Routledge, 1990.

HARLAND, R. Superstructuralism. The Philosophy of Structuralismand PostStructuralism. London, Routledge, 1987.

HARVEY, D. The Condition of Postmodernity. Oxford, Basil Blackwell, 1989.

. Between Space and Time: Reflections on the Geographical Imagination. Annals of the Association of American Geographers, v. 80, n. 3, p. 418-34, 1990.

HASSAN, I. The Dismemberment of Orphens: Towards a Postmodern Literature. New York, Oxford University Press, 1971. . The Postmodern Turn. Essays in Postmodern Theory and Culture. Columbus, Ohio, State University Press, 1987.

HECKSCHER, C.; DONNELLON, A. (eds). The PostBureaucratic Organization. New Perspectives on Organizational Change. London, Sage, 1994.

JAMESON, F. Postmodernism, or the cultural logic of late capitalism. New Left Review, 146, p. 53-65, 1984. Postmodernism, or, the Cultural Logic of Late Capitalism. London, Verso, 1991.

JEANNIERE, A. Les fins du monde. Paris, Aubier, 1987.

JENCKS, C. The language of post-modern architecture. London, New York, Academy/St-Martin's Press, 1977a. . Mouvements modernes en architecture. Bruxelles, Mardaga, 1976b. What is Post-Modernism? London, New York, Academy, St-Martin's Press, 1986. . Heteropolis: Los Angeles, the Riots, and the Strange Beauty of Hetero-Architecture. London, Academy Editions, 1993. 
JONAS, H. Le principe responsabilité. Paris, Cerf, 1990.

KLING, R.; OLIN, S.; POSTER, M. Postsuburban California. Berkeley, University of California Press, 1991.

LAMBERT, Y. Vers une ère post-chrétienne? Futuribles, n. 200, p. 85-111, 1995.

LYOTARD, J-F. Des dispositifs pulsionnels. Paris, Union Générale d'Edition, 1973, 10/18.

La condition postmoderne. Paris, Ed. Minuit, 1979.

. Discussion, ou: pharser "après Auschwitz"'. In LACOUE-LABARTHE, P.; NANCY, J.F. (eds). Les fins de l'homme. Autour du travail de Jacques Derrida. Paris, Galillée, 1981, p. 283-315.

. Response à la question: qu'est-ce que le postmoderne. Critique, v. 37, n. 419, p. 357-67, 1982.

. La peinture du secret à l'ère postmoderne, Baruchello. Traverses, n. 30/31, p. 95-101, 1984.

MESCHONNIC, H. Modernité Modernité. Lagrasse, Ed. Verdier, 1988.

MILLS, D. Q. L'entreprise post-hiérarchique. Paris, InterEditions, 1994.

NICHOLSON, L. (ed.) Feminism/Postmodernism. London, Routledge, 1990.

PASQUIER, D. Vingt ans de recherches sur la télévision: une sociologie post lazarsfeldienne, Sociologie du Travail, v. 36, n. 1, p. 63-84, 1994.

PEET, R.; WATTS, M. Introduction: development Theory and Environment in an Age of Market Triumphalism. Economic Geography, 69, 3/4, p. 227-253, 1993.

PORTOGHESI, P. Au-delà de lárchitecture moderne. Paris, L'Equerre, 1981.

. Le post-moderne. L'architecture dans la société postindustrielle. Paris, Electra Moniteurs, 1983.

POULAT, E. L'ére postchrétienne. Paris, Flammarion, 1994.

PRATT, G. Reflexions on Poststructuralism and Feminist Empirics, Theory and Practice. Antipode, v. 25, n. 1, p. 5163, 1988.
ROSENBERG, H. The Tradition of the New. Chicago, Chicago University Press, 1960.

SCHUURMAN, F. J. Beyond the Impasse: New Directions in Development Theory. London/New Jersey, Zed Books, 1993.

SCOTT, A. J. Metropolis. Los Angeles, University of California Press, 1988.

SERRES, M. Le contrat naturel. Paris, Flammarion, 1990.

SOJA, E. W. Aménager dans/pour la post-modernité. Espaces et Sociétés, n. 74/75, p. 203-14, 1993.

SOPER, K. Feminism, humanism and postmodernism. Radical Philosophy, n. 55, p. 11-17, 1990.

TOURAINE, A. Modernité et spécificités culturelles. Revue Internationale des Sciences Sociales, n. 118, p. 497-511, 1988. . Critique de la modernité. Paris, Fayard, 1992.

VAKALOULIS, M. Post-capitalisme ou capitalisme e postmoderne? Structures fondamentales et facteurs de nouveauté. Futur Antérieur, n. 21, p. 45-57, 1994a.

VATTINO, G. La fin de la modernité. Nihilism et herméneutique dans la culture post-moderne. Paris, Seuil, 1987 (1985).

VIRILIO, P. L'art du moteur. Paris, Galilée, 1993. . La vitesse de libération. Paris, Galilée, 1995.

WEINSTEIN, D.; WEINSTEIN, M. Postmodern(ized) Simmel. London, Routledge, 1993.

WELLMER, A. In Defence of Modernity. Cambridge, Polity Press, 1990.

. The Persistence of Modernity. Essays on Aesthetics, Ethics and Postmodernism. Cambrigde, Polity Press, 1991.

WELSCH, W. Modernité et Postmodernité. Les Cahiers de Philosophie, 6, p. 21-31, 1988.

WOLIN, R. Modernism vs. Postmodernism. Telos, n. 62, p. 9-29, 1984.

YOUNG, R. Post-colonial Theory. Oxford, Blackwell, 1987. 